\title{
46 PROXIMITY BETWEEN CYTOTOXIC ANTIGEN- EXPERIENCED T CELLS AND TUMOR CELLS IS ASSOCIATED WITH IMPROVED CLINICAL OUTCOMES IN EARLY-STAGE NSCLC
}

Qianyun Luo*, Edwin Parra, Marcelo Negrao, Neal Akhave, Erin Bayley, Kyle Mitchell, Jianjun Zhang, John Heymach, Boris Sepesi, Ignacio Wistuba, Don Gibbons, Alexandre Reuben. The University of Texas MD Anderson Cancer Center, Houston, TX, United States

Background While the development of immunotherapies has improved the treatment of non-small cell lung cancer (NSCLC), most patients still fail to respond. Immune cell densities have been utilized to predict clinical responses but have largely failed to do so. However, the spatial distribution and interaction of these cells at the tissue level have been less studied. Here, we performed spatial analysis of the cells within the tumor immune microenvironment in order to evaluate their relationship with clinical outcomes in early-stage NSCLC.

Methods Multiplex immunofluorescence was performed on 123 early-stage NSCLC patients from the ICON (Immunogenomic profiling of non-small cell lung cancer) cohort including Cytokeratin (CK), CD3, CD8, CD45RO, FoxP3, CD68, CD20, CD57, Granzyme B (GzmB), PD-1, and PD-L1. Area under the curve (AUC) was calculated using Ripley's L function, which evaluates the degree of spatial proximity of two cell populations, with a high AUC indicating clustering and low AUC indicating scattering. Findings were integrated with clinical parameters.

Results Adenocarcinomas demonstrated CD3+PD1+ T cells were closer to $\mathrm{CK}+$ tumor cells $(\mathrm{n}=60, \mathrm{p}=0.035)$, and $\mathrm{B}$ cells were closer to cytotoxic $\mathrm{T}$ cells $(n=43, \mathrm{p}=0.03)$ than in squamous cell carcinoma. Higher AUC was observed between CD3 $+\mathrm{PD} 1+\mathrm{T}$ cells $(\mathrm{n}=56, \mathrm{p}=0.035)$, with cytotoxic antigenexperienced $\mathrm{T}$ cells $(\mathrm{CD} 45 \mathrm{RO}+\mathrm{GzmB}+)$ closer to tumor cells $(\mathrm{n}=35, \mathrm{p}=0.017)$ in stage I and II compared to stage III tumors. Untreated patient tumors exhibited higher proximity between $\mathrm{CD} 20+\mathrm{B}$ cells and CD57+ NK cells $(\mathrm{n}=59$, $\mathrm{p}=0.012), \mathrm{CD} 3+\mathrm{T}$ cells and PD-L1+ tumor cells $(\mathrm{n}=56$, $\mathrm{p}=0.027)$, and CD68 + macrophages and PD-L1+ tumor cells $(\mathrm{n}=52, \mathrm{p}=0.016)$ than neoadjuvant chemotherapy-treated patients. Patients with no recurrence presented higher AUC in antigen-experienced $\mathrm{CD} 45 \mathrm{RO}+\mathrm{GzmB}+\mathrm{T}$ cells and tumor cells $(n=36, p=0.006)$, while those with improved survival demonstrated greater proximity between $\mathrm{CD} 68+$ macrophages and PD-L1+ tumors $(\mathrm{n}=52, \mathrm{p}=0.016), \mathrm{CD} 20+\mathrm{B}$ cells and $\mathrm{GzmB}$ + cells $(n=49, p=0.03)$, and antigen-experienced CD45RO $+\mathrm{GzmB}+\mathrm{T}$ cells and tumor cells $(\mathrm{n}=36, \mathrm{p}=0.047)$. Lastly, patients with improved survival also displayed greater proximity between CD3 + CD8 + cytotoxic T cells and PD-L1- epithelial cells $(n=76, p=0.04)$ in tumors versus matched adjacent lungs.

Conclusions Overall, our findings shed light on some of the potential cell interactions at play in the tumor microenvironment of early-stage NSCLC patients and suggest cell distributions could be utilized to predict clinical outcomes in earlystage NSCLC patients.

http://dx.doi.org/10.1136/jitc-2021-SITC2021.046 